\title{
BioLink
}

Jurnal Biologi Lingkungan, Industri, Kesehatan

Available online http://ojs.uma.ac.id/index.php/biolink

\section{PERSEPSI MASYARAKAT TENTANG IMUNISASI MR PUSKESMAS GLUGUR DARAT KECAMATAN MEDAN TIMUR 2019}

\section{COMMUNITY PERCEPTION ABOUT IMMUNIZATION OF MR PUSKESMAS GLUGUR DARAT KECAMATAN MEDAN TIMUR 2019}

\author{
Eva Latifah Nurhayati ${ }^{*}$ dan Debi Novita Siregar ${ }^{2}$ \\ ${ }^{1}$ Diploma Keperawatan, Fakultas Keperawatan dan Kebidanan, Universitas Prima Indonesia \\ ${ }^{2}$ Diploma Kebidanan, Fakultas Keperawatan dan Kebidanan, Universitas Prima Indonesia \\ Diterima : 22-08-2019; Disetujui : 10-01-2020: Diterbitkan : 10-02-2020 \\ *Corresponding author: E-mail: nurhayati_latifah@yahoo.com
}

\begin{abstract}
Abstrak
Penelitian ini bertujuan untuk mengetahui bagaimana persepsi masyarakat tentang imunisasi MR, Adapun yang menjadi latar belakang penelitian ini disebabkan di masyarakat banyak terjadi pro kontra dalam pelaksanaan imunisasi MR ini. Penelitian ini bersifat kuantitatif dengan studi kasus di Puskesmas Glugur Darat. Populasi adalah masyarakat yang memiliki anak usia 9 bulan sampai 15 tahun. Penentuan sampel tersebut dengan quota sampling. Dengan jumlah sampel sebanyak 100 orang. Instrumen pengambilan data dengan dokumentasi, angket dan wawancara langsung yang kemudian dianalisis menggunakan korelasi linier sederhana. Dari hasil penelitian ini menunjukkan persepsi masyarakat tentang Imunisasi MR di Wilayah Kerja Puskesmas Glugur Darat mayoritas 71\% belum memahami tentang imunisasi MR. Dan dari hasil uji chi quare untuk menganalisis hubungan antara persepsi masyaratakat tentang imunisasi MR dan keikutsertaan Imunisasi MR diperoleh hasil nilai $\mathrm{p}=$ 0,000.maka ada hubungan antara persepsi masyarakat tentang imunisasi MR dengan keikutsertaan imunisasi MR. Bagi puskesmas glugur darat untuk memberikan informasi kepada masyarakat tentang imunisasi MR dengan memberikan penyuluhan kepada masyarakat, pembagian leaflet tentang imunisasi MR.
\end{abstract}

Kata Kunci: MR, imunisasi, Masyarakat, Persepsi

\begin{abstract}
This study aims to find out how people's perceptions about MR immunization, as for the background of this research is because, in the community, there are many pros and cons in the implementation of MR immunization. This research is quantitative with a case study in Glugur Darat Health Center. The population is the community that has children aged nine months to 15 years. Determination of the sample with quota sampling. With a total sample of 100 people. Data collection instruments with documentation, questionnaires and direct interviews which are then analyzed using simple linear correlation. From the results of this study indicate the public perception of MR Immunization in the Work Area of the Glugur Darat Health Center, the majority of $71 \%$ do not understand about MR immunization. And from the results of the chi-square test to analyze the relationship between the perception of the community about MR immunization and the participation of MR immunization, the results obtained $p=0,000$. Then there is a relationship between the public perception of $M R$ immunization with the participation of $M R$ immunization. For onshore Glugur health centers to provide information to the public about MR immunization by providing counselling to the community, distributing leaflets about MR immunization.
\end{abstract}

Key Words: MR, Immunization, community, perception

How to Cite: Nurhayati, E.L. dan Siregar, D.B. (2020). Persepsi Masayarakat Tentang Imunisasi MR di Puskesmas Glugur Darat Kecamatan Medan Timur 2019, BioLink: Jurnal Biologi Lingkungan, Industri dan Kesehatan, Vol.6 (2): Hal. 171-177 


\section{PENDAHULUAN}

Program imunisasi sebagai upaya pelayanan kesehatan dapat meningkatkan kekebalan secara aktif terhadap suatu penyakit pada balita. Tujuan jangka pendek diberikan imunisasi untuk pencegahan penyakit perorangan maupun kelompok, tujuan jangka panjangnya yaitu eliminasi penyakit. Imunisasi MR (Measles, Rubella) di gunakan untuk memberikan kekebalan terhadap penyakit campak dan rubella. Dalam imunisasi MR, antigen yang di pakai virus campak strain Edmonson, virus rubella strai RA 27/3, serta virus gondog. Vaksin ini tidak dianjurkan untuk anak 1 tahun ke bawah karena ditakutkan terjadi kontraindikasi dengan antibodi yang ada pada anak tersebut.

Pemberian imunisasi MR ini bertujuan agar terbentuknya kekebalan terhadap penyakit campak, dan campak jerman dan memberikan perlindungan terhadap kedua penyakit tersebut pada saat yang bersamaan. Mulai tahun 2017, untuk melengkapi lima imunisasi dasar lengkap, serta menekan angka kesakitan dan kematian anak Pemerintah telah menambahkan imunisasi MR yang sebelumnya MMR, Japanese Encephalitis (JE) dan Pnemokokus. Pelaksanaan kampanye vaksin MR dengan pengenalan (introduksi) imunisasi Rubella kedalam program imunisasi nasional memakai vaksin MR (Measles, Rubella) menggantikan vaksin campak yang selama ini dipakai dengan sasaran anak berusia 9 bulan sampai $<15$ tahun.

Pada tahun 2020, Indonesia mentargetkan terjadinya eliminasi campak dan Rubella. Berdasarkan hasil surveilans, cakupan imunisasi campak rutin saja belum cukup untuk mencapai target tersebut. Maka diperlukan kampanye imunisasi MR pada saat imunisasi. Kampanye imunisasi MR ini akan dilaksanakan pada bulan Agustus September 2017 di seluruh Pulau Jawa dan Agustus -September 2018 di seluruh Pulau Sumatera, Kalimantan, Sulawesi, Nusa Tenggara, Maluku dan Papua

Dirjen PPKP Kementerian Kesehatan Republik Indonesia pada tahun 2017 mengeluarkan petunjuk teknis kampanye imunisasi Measles Rubela (MR), dan pada Tahun 2018 dibulan agustus sampai september, di Indonesia mengadakan imunisasi MR secara nasional pada buan agustus yang dilaksanakan disekolah TK, SD, dan SMP. sedangkan pada bulan September untuk usia balita, yang dilaksanakan di puskesmas. Di masyarakat banyak terjadi pro kontra dalam pelaksanaan imunisasi MR ini, sehingga peneliti merasa tertarik untuk mengetahui bagaimana persepsi masyarakat tentang 
imunisasi MR sehingga peneliti akan mengetahui bagaimana pengetahuan masyarakat serta keikutsertaan dalam kegiatan imunisasi MR yang dilaksanakan serentak pada bulan Agustus dan September.

\section{METODE PENELITIAN}

Metode yang digunakan dalam penelitian adalah metode kuantitatif dengan studi kasus, yaitu untuk mengetahui persepsi masyarakat tentang imunisasi MR di Puskesmas Glugur Darat dan keikutsertaan vaksinasi MR di wilayah tersebut. Jenis data yang dikumpulkan adalah data primer, yang peneliti peroleh langsung dari responden dengan melakukan wawancara terstruktur. Selain itu peneliti juga menggunakan data sekunder yang peneliti peroleh dari Puskesmas Glugur Darat untuk mengetahui berapa jumlah balita dan lingkungan mana yang termasuk dalam wilayah Puskesmas Glugur Darat. Populasi adalah masyarakat memiliki anak 9 bulan Tabel 1. Distribusi Frekuensi Jawaban Responden Per Pertanyaan (n=100)

\begin{tabular}{|c|c|c|c|c|c|c|c|c|c|c|}
\hline \multirow{3}{*}{ No } & \multirow{3}{*}{ Pernyataan } & \multicolumn{8}{|c|}{ Kategori Penilaian } & \multirow{3}{*}{ JUmlah } \\
\hline & & \multicolumn{2}{|c|}{ SS } & \multicolumn{2}{|c|}{$\mathrm{S}$} & \multicolumn{2}{|c|}{ TS } & \multicolumn{2}{|c|}{ STS } & \\
\hline & & $\mathrm{f}$ & $\%$ & $\mathrm{f}$ & $\%$ & $\mathrm{f}$ & $\%$ & $\mathrm{f}$ & $\%$ & \\
\hline 1 & $\begin{array}{l}\text { Penyakit infeksi menular melalui saluran } \\
\text { nafas yang disebabkan oleh vuris adalah } \\
\text { Penyakit Campak Rubella }\end{array}$ & 8 & 8 & 38 & 38 & 38 & 38 & 16 & 16 & 100 \\
\hline 2 & $\begin{array}{l}\text { Anak serta orang dewasa yang belum } \\
\text { pernah mendapat imunisasi campak dan } \\
\text { rubella atau yang belum pernah mengalami } \\
\text { penyakit ini tidak berisiko tinggi tertular }\end{array}$ & 12 & 12 & 36 & 36 & 36 & 36 & 16 & 16 & 100 \\
\hline 3 & $\begin{array}{l}\text { Komplikasi dari campak antara lain diare, } \\
\text { radang paru pneumonia, radang otak,gizi } \\
\text { buruk kebutaan bahkan kematian }\end{array}$ & 8 & 8 & 46 & 46 & 24 & 24 & 22 & 22 & 100 \\
\hline
\end{tabular}


4 Rubella bila menulari ibu hamil pada trimester pertama dapat menyebabkan keguguran atau kecacatan pada bayi yang dilahirkan.

5 demam tinggi, bercak kemerahan pada kulit disertai batuk, pilek, dan mata merah (konjungtivitis)merupakan gejala campak

6 Gejala rubella tidak spesifik bahkan tidak menumbulkan gejala sama sekali. antara lain mata merah, dan nyeri pada persendian. Mirip gejala flu.

7 Pencegahan campak dan rubella adalah dengan imunisasi MR/ Vaksin MR

8 Vaksin MR adalah kombinasi vaksin campak dan rubella untuk perlindungan terhadap penyakit campak dan rubella

9 WHO telah memberikan rekomendasi vaksin dan adanya izin dari Badan POM bahwasanya MR efektif untuk mencegah campak dan rubella.

10 Imunisasi MR tidak diberikan untuk anak usia 9 bulan sampai dengan kurang dari 15 tahun

11 Demam ringan, ruam merah, bengkak ringan, dan nyeri di tempat suntikan akan menghilang dalam 2-3 hari

12 Apabila anak telah diimunisasi campak apakah perlu mendapat imunisasi MR

13 untuk mendapat kekebalan terhadap rubella. Imunisasi MR tidak aman bagi anak yang telah mendapat 2 dosis imunisasi campak

14 Vaksin MR tidak mencegah penyakit campak dan rubella

15 Pemerintah memprioritaskan pengendalian campak dan rubella karena dapat dapat menyebabkan kematian

16 Imunisasi MR tidak aman diberikan kepada anak yang sudah mendapat vaksin MMR

17 Sampai saat ini tidak ada ditemukan bahwa imunisasi dapat menyebabkan autisme

18 fatwa nomor 33 tahun 2018, MUI menyatakan dibolehkan menggunaan vaksin MR dari Serum Institute of India (SII) untuk program imunisasi saat ini

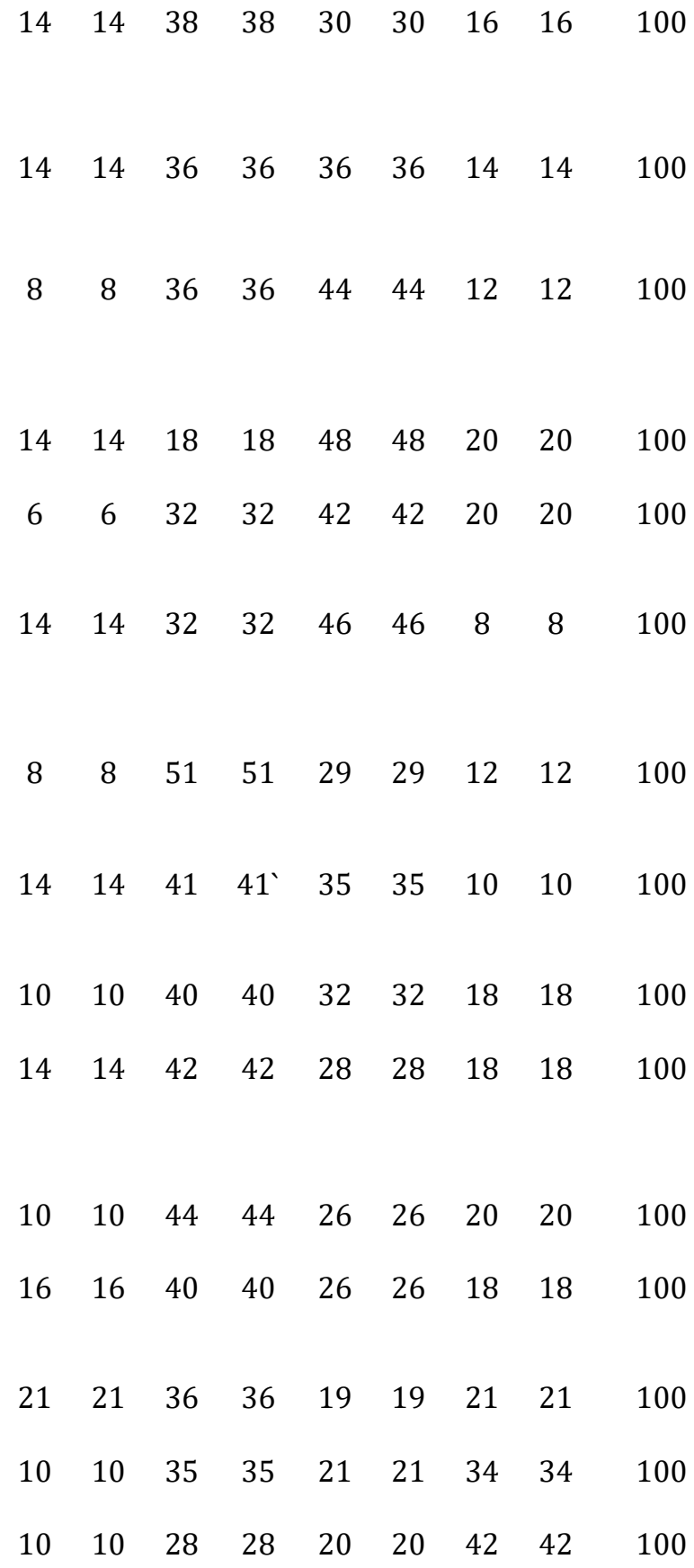

Data yang dikumpulkan adalah data setuju (36\%). Pernyataan ketiga yang di Puskesmas Glugur darat, dari 18 menjawab setuju (46\%). Pernyataan pernyataan yang diajukan kepada 100 keempat mayoritas responden menjawab responden, Pernyataan pertama mayoritas setuju $\quad$ (38\%), Pernyataan kelima menjawab tidak setuju dan setuju (38\%). mayoritas responden menjawab tidak Pernyataan kedua responden menjawab setuju dan setuju (36\%). . Pernyataan 
keenam mayoritas respondnen menjawab tidak setuju (44\%). Pernyataan ketujuhmayoritas responden menjawab tidak setuju (48\%). Pernyataan kedelapan mayoritas responden menjawab tidak setuju (42\%). Pernyataan kesembilan mayoritas responden menjawab tidak setuju (46\%). Pernyataan kesepuluh menjawab setuju (51\%). Pernyataan kesebelas mayoritas responden menjawab setuju (41\%). Pernyataan kedua belas responden mayoritas menjawab setuju sangat tidak setuju (42\%).

Tabel 2. Distribusi frekuensi persepsi masyarakat tentang imunisasi MR

\begin{tabular}{ccc}
\hline Kategori & f & \% \\
\hline Persepsi & & \\
Baik & 29 & 29 \\
Tidak baik & 71 & 71 \\
\hline Total & & $\mathbf{1 0 0}$ \\
\hline
\end{tabular}

Berdasarkan tabel 2 diketahui bahwa persepsi masyarakat tentang imunisasi MR mayoritas memiliki persepsi yang tidak baik tentang imunisasi MR (71\%) dan minoritas memiliki persepsi baik tentang imunisasi MR (29\%). Dari hasil wawancara peneliti dengan responden mereka banyak yang tidak mengetahui tentang imunisasi MR, Petugas kesehatan juga kurang mensosialisasikan imunisasi

masyarakat minim informasi tentang imunisasi MR. Dalam hal ini selain petugas kesehatan dari puskemas Glugur Darat, peran kader, kepala lingkungan juga sangat penting untuk memberikan informasi tentang imunisasi MR.karena kader dan kepala lingkungan adalah orang yang saat ini dekat dengan masyrakat. Untuk kader kesehatan di lingkungan III sendiri belum ada.

MR kepada masyarakat, sehingga

Tabel 3. Distribusi Frekuensi Keikutsertaan imunisasi MR

\begin{tabular}{ccc}
\hline Kategori & f & $\mathbf{\%}$ \\
\hline Keikutsertaan & & \\
Imunisasi MR & & \\
Ikut & 70 & 70 \\
Tidak ikut & 30 & 30 \\
\hline Total & & $\mathbf{1 0 0}$ \\
\hline
\end{tabular}


Berdasarkan tabel 3 diketahui bahwa di posyandu, maupun di sekolah. Mereka keikutsertaan imunisasi MR mayoritas ada yang diimunisasi di posyandu, ikut serta dalam imunisasi MR (70\%) baik puskesmas dan disekolah-sekolah mereka.

Tabel 4. Hubungan Persepsi Masyarakat tentang Imunisasi MR dengan Keikutsertaan Imunisasi MR

\begin{tabular}{|c|c|c|c|c|c|c|c|c|}
\hline \multirow{4}{*}{$\begin{array}{c}\text { Persepsi } \\
\text { Masyarakat } \\
\text { Tentang } \\
\text { Imunisasi Mr }\end{array}$} & \multicolumn{8}{|c|}{ Keikutsertaan Imunisasi MR } \\
\hline & \multirow{2}{*}{\multicolumn{2}{|c|}{ Ikut serta }} & \multirow{2}{*}{\multicolumn{2}{|c|}{$\begin{array}{c}\text { Tidak ikut } \\
\text { serta }\end{array}$}} & \multicolumn{2}{|c|}{ Total } & \multirow{2}{*}{$\alpha$} & \multirow{2}{*}{$p$-value } \\
\hline & & & & & & & & \\
\hline & $\mathrm{f}$ & $\%$ & $\mathrm{f}$ & $\%$ & $\mathrm{f}$ & $\%$ & \multirow{3}{*}{0,05} & \multirow{3}{*}{0,000} \\
\hline Baik & 28 & 28 & 1 & 1 & 29 & 29 & & \\
\hline Tidak Baik & 42 & 42 & 29 & 29 & 71 & 71 & & \\
\hline Total & 70 & 70 & 30 & 30 & 100 & 100 & & \\
\hline
\end{tabular}

Berdasarkan hasil uji chi-square didapatkan nilai p-value 0,000 Hal ini berarti $p$-value $<(0,05)$ yang berarti ada hubungan antara persepsi masyarakat tentang imunisasi MR dengan keikutsertaan imunisasi MR di puskesmas glugur darat.(92,3\%)

Menurut hasil penelitian Marlinta (2018) bahwasanya terdapat hubungan persepsi tentang vaksin MR dengan keikutsertaan vaksinasi MR, tidak terdapat hubungan pendidikan ibu dengan minat keikutsertaan vaksinasi MR. Gayuh Mustika dkk (2018) hasil penelitian menunjukkan dari hasil uji Chi square bahwasanya ada hubungan pengetahuan $(p=0,006)$, persepsi keparahan $(p=0,012)$, dengan penerimaan ibu terhadap imunisasi MRpada Anak SD di Desa Gumpang Kecamatan Kartasura Kabupaten Sukoharjo.
Imunisasi MR merupakan program yang baru dicanangkan pemerintah untuk dapat menekan kejadian akibat campak dan rubella. Pemberian imunisasi MR merupakan yang pertama kali dilakukan dan masih menimbulkan perdebatan di dalam masyarakat. Masih terdapat masyarakat tidak mengizinkan pemberian imunisasi MR disebabkan kesadaran orang tua terhadap pentingnya imunisasi bagi anak masih rendah, isu yang beredar bahwa imunisasi MR mengandung vaksin yang berbahaya, dan status kehalalan vaksin. Meskipun kampanye imunisasi merupakan program wajib dilaksanakan di sekolah dan pos pelayanan kesehatan, masih terdapat sekolah yang belum mewajibkan program kampanye imunisasi MR. 


\section{SIMPULAN}

Hasil penelitian ini didapatkan berdasarkan analisis univariat bahsawanya persepsi masyarakat tentang imunisasi MR di Puskesmas Glugur Darat mayoritas persepsi tidak baik (71\%) Keikutsertaan masyarakat untuk imunisasi MR di Puskesmas Glugur Darat mayoritas ikut serta dalam imunisasi MR (70\%). Berdasarkan hasil analisis bivariat bahwasanya ada hubungan antara persepsi masyarakat tentang imunisasi MR dengan keikutsertaan imunisasi MR dengan nilai $p$ value 0,000 .

\section{UCAPAN TERIMAKASIH}

Ucapan terima kasih kepada RistekDIkti yang memberikan dana Penelitian Dosen Pemula, LPPM UNPRI, Rektor UNPRI, Dekan FKK UNPRI yang telah memberikan motivasi kepada peneliti.

\section{DAFTAR PUSTAKA}

Arista, D. \& Hosana. ( 2016 ). Hubungan Tingkat Pendidikan, Dukungan Keluarga dan Peran Tenaga Kesehatan Dengan Riwayat Pemberian Imunisasi Dasar pada Bayi di Wilayah Kerja Puskesmas Paal V Kota Jambi Tahun 2016. Scientia Journal, 5 (2): 157-166. Appl. Sci. Environ. Manage. 11(4): 81-84

Dahlan, M. S., (2015). Statistik untuk Kedokteran dan Kesehatan.6 ed.Jakarta: Epidemiologi Indonesia.

Direktorat Jenderal Pencegahan dan Pengendalian Penyakit UNICEF. Paket Advokasi Imunisasi Massal Campak Rubella AgustusSeptember 2018

Kemenkes. (2016). Petunjuk Teknis Kampaye Imunisasi Measles dan Rubella (MR). Jakarta: Direktorat Jendral Pencegahan dan Pengendalian Pneyakit Kemenkes RI;
Kemenkes. (2017a). Petunjuk Teknis Kampanye dan Introduksi Imunisasi Maesles Rubella (MR). Jakarta: Direktorat Jenderal Pencegahan dan Pengendalian Penyakit Kementerian Kesehatan Republik Indonesia..

Kemenkes. (2017b). Status Campak dan Rubella Saat Ini di Indonesia. Jakarta: Kementerian Kesehatan Republik Indonesia.

Kemenkes. (2017c). Data dan Informasi: Profil Kesehatan Indonesia 2016. Jakarta: Pusat Data dan Informasi Kementerian Kesehatan Republik Indonesia.

Kemenkes. (2018). Paket Imunisasi Massal Campak-Rubella Agustus - September 2018. Jakarta: Kemenkes RI;

Kemenkes; WHO \& UNICEF. (2018). Paket Imunisasi Massal Campak-Rubella Agustus - September 2018. Jakarta: Kemenkes RI;

Lailan Najah, 2017. Tingkat Pengetahuan Ibu Tentang Imunisasi Tambahan MR (Measles Rubella) Pada Balita di Puskesmas Kotagede I Yogyakarta.

Gayuh Mustika Prabandari, Syamsudin Budi Mustofa, Aditya Kusumawati, (2018). Beberapa Faktor Yang berhubungan dengan Penerimaan Ibu terhadap Imunisasi Measles Rubella Pada Anak SD di Desa Gumpang Kecamatan Kartasura Kabupaten Sukoharjo. Jurnal Kesehatan Masyarakat, Volume 6, Nomor 4, Agustus 2018

Kusumawati. (2019) Pemberian imunisasi MR pada Anak di TK Kota Semarang. Jurnal Pengabdian Masyarakat Kebidanan. Volume 1 no 2

Merlinta, (2018). Hubungan Pengetahuan Tentang Vaksin MR (Measles Rubella) dan Pendidikan Ibu terhadap Minat Keikutsertaan Vaksinasi MR di Puskesmas Kartasura, Jurnal Ilmiah Kesehatan, Volume 5 No. 1, 2018.

Muslimah, (2019). Persepsi Ibu Terhadap iklan Vaksin Measles Rubella (MR). Hasanuddin Journal Of Midwifery (HajoM) Volume 1 No 1 .

Proverawati, A. \& Dwi Andhini, C. S., (2010). Imunisasi dan Vaksinasi.Yogyakarta: Nuha Medika.

Tristan (2019). Faktor-faktor yang mempengaruhi minat imunisasi Measles Rubella(MR) di Kecamatan Malalayang, Manado. Jurnal Medik dan Rehabilitasi vol 1 No 3

Notoatmodjo, Soekidjo. (2012). Metodelogi Penelitian Kesehatan, cetakan. 1, Jakarta, PT Rineka Cipta 